\title{
DNA nanotechnology: a curiosity or a promising technology?
}

\section{Thomas Tørring and Kurt V. Gothelf*}

\author{
Address: Center for DNA Nanotechnology (CDNA) at the Interdisciplinary Nanoscience Center (iNANO), Aarhus University, \\ 8000 Aarhus C, Denmark \\ * Corresponding author: Kurt V. Gothelf (kvg@chem.au.dk) \\ Fl000Prime Reports 2013, 5:14 (doi:10.12703/P5-14) \\ This is an open-access article distributed under the terms of the Creative Commons Attribution-Non Commercial License \\ (http://creativecommons.org/licenses/by-nc/3.0/legalcode), which permits unrestricted use, distribution, and reproduction in any medium, \\ provided the original work is properly cited. You may not use this work for commercial purposes. \\ The electronic version of this article is the complete one and can be found at: http://fl 000.com/prime/reports/b/5/I4
}

\begin{abstract}
DNA nanotechnology, the design and self-assembly of artificial nucleic acid-based structures or systems, has developed with breathtaking pace in recent years. The technology offers an unparalleled ability to control structure and function at the molecular level and the sizes of the structures are expanding towards the micrometer domain. The question is whether the technology offers solutions to any real-life problems, or if it will remain an academic discipline. Here, we discuss this question by extrapolating from recent developments in the field.
\end{abstract}

\section{Introduction}

DNA nanotechnology has evolved from Ned Seeman's work on immobile DNA junctions and his vision about organizing proteins and other materials in lattices created by such junctions $[1,2]$. The first revolution in the field was the development of tile-based 2D structures in the late nineties, as such structures enabled imaging by atomic force microscopy and provided new structural insights [3]. In 2003, Yan et al. [4] proposed the implementation of longer scaffold strands as templates for tile assembly. One year later, in 2004, Shih et al. reported the design and assembly of octahedral DNA, consisting primarily of a long singlestranded heavy chain [5]. These advances led to the second major breakthrough, namely the invention of the DNA origami method by Paul Rothemund in 2006 that suddenly enabled design and formation of arbitrarily shaped DNA nanostructures containing around half a million atoms or around 14,000 nucleotides $[1,2,6]$. This method soon evolved from $2 \mathrm{D}$ into $3 \mathrm{D}$, and recently a complementary and more modular DNA tile/brick-based method has been developed [7-9]. Typical sizes of such DNA nanostructures are $100 * 70 \mathrm{~nm}^{2}$ for 2D DNA origami and $25 * 25 * 25 \mathrm{~nm}^{3}$ for 3D DNA origami structures, but obviously this depends on the scaffold used and the structure design.

Many intriguing structures, ranging from 2D structures, solid brick structures, DNA boxes and spheres, tensegrity structures, various polyhedra, DNA structures with curvature and so forth, have been made [7]. Furthermore, several dynamic structures have been made, including walkers following designed tracks inspired by motor proteins such as dynein and kinesin [10]. While these examples have demonstrated the structural and functional power of DNA origami, none of these structures have any applications.

The main challenges for extension of DNA nanotechnology to real-life applications are to find ways to take advantage of the structural and dynamic features. The complexity of the structures used in DNA nanotechnology is a double-edged sword. The advantages are the freedom to attach a plethora of functionalities e.g. proteins, small molecules or inorganic materials in any desired pattern or orientation. The downsides of this complexity are typically low yield, small production scale, and the cost of synthetic DNA. For most academic purposes these disadvantages are not huge, but if these complex structures are to be produced commercially they will have to be addressed.

For some applications it is also a challenge that DNA nanostructures are labile and highly sensitive to ionstrength, temperature and nucleases. Furthermore, as a material, DNA nanostructures are soft and still so small 
that it is very difficult to address individual structures efficiently. However, there are a number of examples, in particular in the recent literature that indicate solutions to at least some of these challenges, and in the following overview we will discuss them together with an assessment of the future potential of DNA nanotechnology.

\section{Functional DNA nanostructures}

One of the first applications of DNA origami was for structure determination of membrane proteins by nuclear magnetic resonance (NMR). William Shih and co-workers designed $0.8 \mu \mathrm{m}$-long dimers of DNA-origami six-helix bundles and these nanotubes served as a detergent-resistant liquid crystal to induce weak alignment of membrane proteins [11]. The alignment allowed accurate measurement of backbone residual dipolar couplings and this was first used for NMR structure determination of a protein with a known structure previously determined by X-ray crystallography. Having verified the method, it was then used to determine the structure of mitochondrial uncoupling protein 2 , a membrane protein with a previously unknown structure [12]. In this scenario, it is simply the DNA origami's ability to form liquid crystals when highly concentrated and its stability in the presence of the detergents used to solubilize membrane proteins that make it a useful tool.

In another recent example, Douglas et al. integrated several degrees of function into a DNA nanostructure to create a DNA robot that could recognize diseased cells and induce apoptosis in them [13]. The recognition of disease-specific proteins at the surface of cells was mediated by aptamers attached to the DNA structure. Upon recognition, the barrel-shaped DNA structure opened and revealed antibodies attached to its interior, and these antibodies in turn induced apoptosis by interaction with other cell surface proteins. This DNA robot was an elegant model system and, while its function was only demonstrated in cell cultures, this example illustrates the great potential of DNA origami as a smart drug. Others have used DNA origami structures as carriers for the anti-cancer drug Doxorubicin [14,15], showing increased potency compared with normal Doxorubicin more curiously it appeared to circumvent the drug resistance normally seen with prolonged use of Doxorubicin. The labs of Liedl and Fan have employed the unique "addressability" of DNA nanostructures to deliver CpGcontaining oligos to cells where they are recognized by Toll-like receptors, leading to increased production of key components of the innate immune system $[16,17]$. Likewise, Anderson's lab at Massachusetts Institute of Technology used a DNA tetrahedron to investigate the performance of 28 different cancer-targeting ligands [18]. After identifying folate as the most effective ligand, they employed the unique addressability of DNA nanostructures to investigate the effect of ligand density and orientation. When combined with siRNA, these nanostructures significantly out-performed the siRNA alone. While much more research is required to address critical issues like stability of the structure towards degradation, immunogenicity, distribution in tissue etc., these initial reports allow for optimism.

In an even more recent example, Langecker et al. created an artificial DNA-origami membrane channel [19]. Again, the function of the structure (in this case the ability to insert into a phospholipid vesicle membrane) was achieved by integrating other materials into the structure. In this case, 26 cholesterol molecules were inserted into a surface of the structure, resulting in the forced penetration of a DNA six-helix bundle through the membrane. The six-helix bundle contains an $\sim 2 \mathrm{~nm}$ cavity and the Munich-based team showed that the channel performs amazingly well on the basis of electrophysiological measurements, which are comparable to natural protein membrane channels. The authors also demonstrated that the DNA channel is an excellent platform for single molecule sensors. What may be even more interesting is the possibility that the DNA channel may be able to interface and communicate with living cells. Furthermore, the demonstration of an artificial DNA structure that can penetrate a lipid membrane may lead to the design of novel DNA-based drug delivery vehicles.

\section{Future perspectives}

With the development of DNA origami, a plethora of academically interesting and aesthetically beautiful DNA nanostructures have been created, but DNA nanotechnology is now moving from design and structure to focus on function. The focus of the examples discussed here have been interactions with biological entities, but the integration of DNA nanostructures in electronic circuits [20-24], or as a tool for studying the interactions between inorganic materials $[25,26]$, are also being pursued. Moreover, 2D DNA origami structures have been used as a platform for a variety of interesting single-molecule studies, most prominently by high-speed atomic force microscopy [27].

Apart from the application of DNA tubes for membrane protein NMR, the most successful approach to create DNA nanostructures with potentially useful function is to modify the structure with other materials, such as organic molecules (cholesterol and folate), proteins (antibodies), aptamers, siRNA and carbon nanotubes. This development has taken place within the last few years and holds great promise for future applications of DNA nanostructures. 
Regarding the size of monodisperse DNA nanostructures, and thereby the ability to address structures individually, there has been a tremendous development since the year 2000 and, in spite of current challenges of expanding DNA origami beyond the size of the M13 genome, there is no reason to believe that the expansion of DNA nanostructure size has come to an end.

A major Achilles heel of the complex 3D DNA nanostructures is the low yields of assembly. Typical yields of $1 \%$ after several days of thermal annealing leave plenty of room for optimization - in particular when considering the upscaling required for realizing many applications. Very recently, the Dietz lab at Technische Universität München have shown that proper analysis of the folding process can reduce the folding time from days to hours, or even minutes [28]. Combined with purification methods appropriate for larger scale [29] and (potentially enzymatic) production methods of the staple strands, this could pave the way for many more real-life applications.

\section{Disclosure}

The authors declare that they have no disclosures.

\section{Acknowledgements}

The authors would like to acknowledge the financial support given by The Danish National Research Foundation to the Center for DNA Nanotechnology (CDNA).

\section{References}

I. Seeman NC: Nucleic acid junctions and lattices. J Theor Biol 1982, 99:237-47.

\section{FlOOOPrime RECOMMENDED}

2. Kallenbach NR, Ma R-I, Seeman NC: An immobile nucleic acid junction constructed from oligonucleotides. Nature 1983, 305:829-31.

\section{FlOOOPrime}

\section{RECOMMENDED}

3. Winfree E, Liu F, Wenzler LA, Seeman NC: Design and selfassembly of two-dimensional DNA crystals. Nature 1998, 394:539-45

\section{FlOOOPrime}

\section{RECOMMENDED}

4. Yan $\mathrm{H}$, Labean $\mathrm{TH}$, Feng $\mathrm{L}$, Reif $\mathrm{H}$ : Directed nucleation assembly of DNA tile complexes for barcode-patterned lattices. Proc Natl Acad Sci USA 2003, 100:8103-8.

\section{FlOOOPrime} RECOMMENDED

5. Shih W, Quispe J: A I.7-kilobase single-stranded DNA that folds into a nanoscale octahedron. Nature 2004, 427:618-2I.

\section{FlOOOPrime}

6. Rothemund PWK: Folding DNA to create nanoscale shapes and patterns. Nature 2006, 440:297-302.

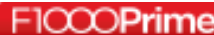

7. Tørring T, Voigt NV, Nangreave J, Yan H, Gothelf KV: DNA origami: a quantum leap for self-assembly of complex structures. Chem Soc Rev 20II, 40:5636-46.

8. Wei B, Dai M, Yin P: Complex shapes self-assembled from single-stranded DNA tiles. Nature 20I2, 485:623-6.

9. Ke Y, Ong LL, Shih WM, Yin P: Three-dimensional structures self-assembled from DNA bricks. Science 20।2, 338:। I77-83.

FlOOOPrime

10. Krishnan Y, Simmel FC: Nucleic acid based molecular devices. Angew Chem Int Ed Engl 20I I, 50:3124-56.

\section{FlOOOPrime \\ RECOMMENDED}

II. Douglas SM, Chou J], Shih WM: DNA-nanotube-induced alignment of membrane proteins for NMR structure determination. 2007, 104:6644-8.

\section{FIOOOPrime \\ RECOMMENDED}

12. Berardi MJ, Shih WM, Harrison SC, Chou JJ: Mitochondrial uncoupling protein 2 structure determined by NMR molecular fragment searching. Nature 201 I, 476:109-3.

\section{FlOOOPrime
RECOMMENDED}

13. Douglas SM, Bachelet I, Church GM: A logic-gated nanorobot for targeted transport of molecular payloads. Science 2012, 335:831-4.

\section{FlOOOPrime}

\section{RECOMMENDED}

14. Jiang Q, Song C, Nangreave J, Liu X, Lin L, Qiu D, Wang Z-G, Zou G, Liang X, Yan H, Ding B: DNA origami as a carrier for circumvention of drug resistance. J Am Chem Soc 2012, 134:13396-403.

\section{FlOOOPrime
RECOMMENDED}

15. Zhao Y-X, Shaw A, Zeng X, Benson E, Nyström AM, Högberg B: DNA origami delivery system for cancer therapy with tunable release properties. ACS Nano 2012, 6:8684-91.

\section{FlOOOPrime}

\section{RECOMMENDED}

16. Li J, Pei H, Zhu B, Liang L, Wei M, He Y, Chen N, Li D, Huang Q, Fan C: Self-assembled multivalent DNA nanostructures for noninvasive intracellular delivery of immunostimulatory CpG oligonucleotides. ACS Nano 20I I, 5:8783-9.

\section{FlOOOPrime}

17. Schüller VJ, Heidegger S, Sandholzer N, Nickels PC, Suhartha NA, Endres S, Bourquin C, Liedl T: Cellular Immunostimulation by CpG-Sequence-Coated DNA Origami Structures. ACS Nano 2011, 5:9696-702.

\section{FlOOOPrime}

\section{RECOMMENDED}

18. Lee $H$, Lytton-Jean AKR, Chen $Y$, Love KT, Park AI, Karagiannis ED, Sehgal A, Querbes W, Zurenko CS, Jayaraman M, Peng CG, Charisse K, Borodovsky A, Manoharan M, Donahoe JS, Truelove J, Nahrendorf M, Langer R, Anderson DG: Molecularly selfassembled nucleic acid nanoparticles for targeted in vivo siRNA delivery. Nat Nanotechnol 2012, 7:389-93.

\section{FlOOOPrime}

\section{RECOMMENDED}

19. Langecker M, Arnaut V, Martin TG, List J, Renner S, Mayer M, Dietz H, Simmel FC: Synthetic lipid membrane channels formed by designed DNA nanostructures. Science 20I2, 338:932-6.

\section{FlOOOPrime}

\section{RECOMMENDED}

20. Kershner RJ, Bozano LD, Micheel CM, Hung AM, Fornof AR, Cha JN, Rettner CT, Bersani M, Frommer J, Rothemund PWK, Wallraff GM: 
Placement and orientation of individual DNA shapes on lithographically patterned surfaces. Nat Nanotechnol 2009, 4:557-6I.

FlOOOPrime

21. Hung AM, Micheel CM, Bozano LD, Osterbur LW, Wallraff GM, Cha JN: Large-area spatially ordered arrays of gold nanoparticles directed by lithographically confined DNA origami. Nat Nanotechnol 2009, 5:121-6.

\section{FlOOOPrime}

\section{RECOMMENDED}

22. Maune HT, Han S-P, Barish RD, Bockrath M, III WAG, Rothemund PWK, Winfree E: Self-assembly of carbon nanotubes into two-dimensional geometries using DNA origami templates. Nat Nanotechnol 20I0, 5:6I-6.

\section{FlOOOPrime}

23. $\mathrm{Xu} \mathrm{PF}, \mathrm{Noh} \mathrm{H}$, Lee JH, Cha JN: DNA mediated assembly of single walled carbon nanotubes: role of DNA linkers and annealing. Phys Chem Chem Phys 20II, 13:10004-8.

\section{FlOOOPrime}

24. Zhao Z, Liu Y, Yan H: DNA origami templated self-assembly of discrete length single wall carbon nanotubes. Org Biomol Chem 2013, II:596-8.

FlOOOPrime RECOMMENDED
25. Kuzyk A, Schreiber R, Fan Z, Pardatscher G, Roller E-M, Högele A, Simmel FC, Govorov AO, Liedl T: DNA-based self-assembly of chiral plasmonic nanostructures with tailored optical response. Nature 20I2, 483:3II-4.

\section{FlOOOPrime \\ RECOMMENDED}

26. Acuna GP, Möller FM, Holzmeister P, Beater S, Lalkens B, Tinnefeld P: Fluorescence enhancement at docking sites of DNA-directed self-assembled nanoantennas. Science 2012, 338:506-10.

\section{FlOOOPrime}

RECOMMENDED

27. Rajendran A, Endo M, Sugiyama H: Single-Molecule Analysis Using DNA Origami. Angew Chem Int Ed 201 I, 5 I:874-90.

\section{FlOOOPrime} RECOMMENDED

28. Sobczak J-PJ, Martin TG, Gerling T, Dietz H: Rapid folding of DNA into nanoscale shapes at constant temperature. Science 2012, 338:|458-6|.

\section{FlOOOPrime}

\section{RECOMMENDED}

29. Lin C, Perrault SD, Kwak M, Graf F, Shih WM: Purification of DNAorigami nanostructures by rate-zonal centrifugation. Nucleic Acids Res 2013, 41:e40.

FlOOOPrime

